\title{
Penerapan Algoritma Winnowing Pada Sistem Rekomendasi Penentuan Dosen Pembimbing Skripsi (Studi Kasus Program Studi Sistem Informasi)
}

\author{
(The Application of Winnowing Algorithm on Recommendation System of thesis supervisor \\ determination (Case Study in Information System Study Program))
}

\author{
Jarwati, Antonius Cahya Prihandoko, Windy Eka Yulia R \\ Sistem Informasi, Program Studi Sistem Informasi,Universitas Jember (UNEJ) \\ Jln. Kalimantan 37, Jember 68121 \\ E-mail: jeje.jarwati@gmail.com
}

\begin{abstract}
Abstrak
Sistem rekomendasi penentuan dosen pembimbing tugas akhir menggunakan algoritma winnowing merupakan sistem yang bertujuan untuk membantu komisi bimbingan menentukan dosen pembimbing. Rekomendasi yang dihasilkan berupa nama dosen yang memenuhi syarat untuk menjadi dosen pembimbing sesuai dengan aturan yang ada pada Program Studi Sistem Informasi. Sistem ini berisikan daftar dosen program studi sistem informasi dan kata kunci penelitian yang pernah dilakukan dosen. Algoritma winnowing digunakan untuk mencari dan menghitung jumlah kata yang sama dalam setiap kata kunci yang dibandingkan. Setiap rekomendasi yang dihasilkan berdasar pada jumlah kesamaan antara kata kunci yang dibandingkan dalam bentuk persentase yang diurutkan dari persentase tertinggi sampai dengan terendah. Sistem rekomendasi ini dibangun berbasis website agar dapat digunakan dengan mudah oleh komisi bimbingan, akademik dan dosen. Algoritma winnowing dipilih karena memiliki keunggulan yakni dapat menangani permasalahan pencocokan string yang bervariasi serta waktu komputasi yang cepat. Pembuatan sistem ini dibangun mengadopsi dari model Waterfall. Sistem rekomendasi penentuan dosen pembimbing ini dirancang dan dibangun dengan 3 (tiga) hak akses, yaitu akademik dan komisi bimbingan dan dosen dengan berbagai fitur yang dapat memudahkan penggunanya. Hasil dari penelitian ini, sistem mampu mengimplementasikan algoritma winnowing untuk membantu komisi bimbingan menentukan dosen pembimbing skripsi sesuai dengan aturan dan kompetensi yang dimiliki dosen
\end{abstract}

Kata Kunci: Algoritma Winnowing, Sistem Rekomendasi, Dosen Pembimbing Skripsi

\section{Abstract}

Recommendation system of final assignment supervisor determination using winnowing algorithm is a system that aimed to help supervising committee determine a supervisor for the students. The results of recommendations system are names of supervisor that qualified to be the supervisor according to the rules in Information System Study Program. This system contain list of lecturer's name and keywords of researches that they have done. Winnowing algorithm is used to search and count the number of similar words for each keyword that being compared. Each recommendation was resulted base on the number of similar keywords that being compared in the form of percentage number that sorted from higher to lower. This recommendation system was built as website-based program so that it will be easy to access by the supervising committee, academic and lecturers. Winnowing algorithm was chosen because it has special quality such as its capability to handle vary matching problem string and it also has fast computation time. The system was built by adopting waterfall model. System on recomendation system of of supervisor determination was planned and built with two access right : first is for academic access and the second is for supervising committee and lecturers access which is completed with easy-to-used features. The result of this research is that the system was able to implemented winnowing algorithm to help supervising committee to determine suitable thesis supervisor according to the rules of the study program and the capability that the lecturers had.

Keywords: Winnowing Algorithm, Recommendation System, Thesis Supervisor Determination

\section{PENDAHULUAN}

Skripsi merupakan tugas akhir bagi mahasiswa untuk mendapatkan gelar sarjana sesuai dengan bidang keahlian yang dituliskan dalam bentuk karya tulis ilmiah. Penulisan karya tulis ilmiah membutuhkan bimbingan dosen pembimbing dari awal penyusunan sampai menghasilkan karya tulis yang berkualitas. Dosen pembimbing berperan penting dalam proses penulisan karya tulis ilmiah sebagai fasilitator, motivator, dan pengarah yang baik sehingga skripsi dapat selesai dan siap untuk diujikan. Penentuan dosen pembimbing harus dilakukan dengan benar sesuai dengan kriteria dan aturan yang berlaku sehingga hasil yang dicapai lebih baik karena penguasaan konsep dan teori yang matang.

Saat ini program studi sistem informasi sedang merintis untuk membuka prodi baru yaitu Teknologi Informasi agar dapat berkembang menjadi sebuah fakultas, maka dapat dipastikan jumlah mahasiswa akan semakin meningkat dan penetapan dosen pembimbing oleh kombi tidak akan sesederhana saat mahasiswa semester akhir masih sedikit. 
Oleh karena itu dibutuhkan suatu sistem rekomendasi yang dapat membantu kombi memilih dosen pembimbing skripsi yang tepat dengan memasukkan kata kunci topik dan judul yang diajukan mahasiswa.

Sistem rekomendasi pemilihan dosen pembimbing skripsi dibuat untuk memilih dosen pembimbing yang sesuai dengan kompetensi, beban kerja dan topik yang dikerjakan mahasiswa. Berdasarkan hal tersebut, terdapat beberapa kriteria yang digunakan dalam pemilihan dosen pembimbing diantaranya yaitu bidang ilmu atau kompetensi, kata kunci penelitian dosen, dan jabatan. Hasil keputusan diperoleh dengan mencocokkan antara kata kunci topik yang diambil mahasiswa dengan kata kunci penelitian yang dilakukan oleh dosen pembimbing dan bidang ilmu yang kemudian dipilih dengan mempertimbangkan jabatan dosen. Salah satu metode yang tepat untuk diterapkan dalam percocokan tersebut adalah algoritma winnowing. Algoritma winnowing menerapkan konsep string matching untuk mencocokkan suatu string dengan string lainnya menggunakan teknik hashing. Pencocokan dapat dilakukan dengan menghitung similarity dari kata kunci penelitian dosen dan kata kunci topik yang dibandingkan.

Sistem rekomendasi pemilihan dosen pembimbing dibangun menggunakan algoritma winnowing. Algoritma winnowing diasumsikan dapat melakukan pencocokan pola string antara kata kunci topik mahasiswa dengan kata kunci penelitian dosen. Implementasi algoritma winnowing pada sistem pendukung keputusan ini dapat memberikan rekomendasi yang tepat sesuai dengan aturan yang berlaku pada prodi Sistem Informasi.

\section{TINJAUAN PUSTAKA}

\section{Metode String Matching}

String matching adalah algoritma yang digunakan untuk memecahkan masalah pencocokan suatu teks terhadap teks lain. Pencocokan string fokus pada pencarian satu atau lebih kesamaan kata dalam sebuah teks (Pertiwi, 2015). Tahap awal yang dilakukan dalam implementasi string matching yaitu ekstraksi informasi menjadi teks terstruktur menggunakan metode text mining .

Metode pendeteksi kesamaan string dibagi menjadi tiga bagian yaitu metode perbandingan teks lengkap, metode dokumen fingerprinting, dan metode kesamaan kata kunci (Kurniawati, 2008) .Berikut ini penjelasan dari masingmasing metode dari algoritma pendeteksi kesamaan:

a. Metode perbandingan teks lengkap diterapkan dengan membandingkan semua isi dokumen. Perbandingan teks lengkap membutuhkan waktu yang lama tetapi cukup efektif, karena kumpulan dokumen yang diperbandingkan adalah dokumen yang disimpan pada penyimpanan lokal. Metode perbandingan teks lengkap tidak dapat diterapkan untuk kumpulan dokumen yang tidak terdapat pada dokumen lokal. Algoritma yang digunakan pada metode ini adalah algoritma Brute-Force, algoritma edit distance, algoritma Boyer Moore dan algoritma lavenshtein distance.

b. Dokumen fingerprinting merupakan metode yang digunakan untuk mendeteksi keakuratan salinan antar dokumen, baik semua teks yang terdapat di dalam dokumen atau hanya sebagian teks saja. Prinsip kerja dari metode dokumen fingerprinting adalah dengan menggunakan teknik hashing. Teknik hashing adalah sebuah fungsi yang mengkonversi setiap string menjadi nilai hash. Algoritma yang digunakan pada metode ini adalah Rabin-Karp, Winnowing dan Manber.

c. Prinsip metode kesamaan kata kunci adalah mengekstrak kata kunci dari dokumen dan kemudian dibandingkan dengan kata kunci pada dokumen yang lain.

\section{Metode Dokumen Fingerprinting}

Prinsip kerja dari metode dokumen fingerprinting adalah dengan menggunakan teknik hashing. Teknik hashing adalah sebuah fungsi yang mengkonversi setiap string menjadi bilangan kemudian menyimpannya dalam sebuah skema atau bagan. Skema digital dokumen fingerprinting terdiri dari sejumlah posisi yang diberi tanda di dalam dokumen, algoritma fingerprinting yang akan memilih tanda yang akan di tambahkan untuk setiap posisi tergantung pada jumlah salinan.

Secara umum prinsip kerja dari metode dokumen fingerprinting adalah dengan tahapan sebagai berikut :

1. Asumsikan teks adalah string s yang panjangnya t.

2. Hilangkan tanda baca dan spasi.

3. Membagi dokumen menjadi k-gram. K-gram digunakan dalam pengambilan potongan karakter huruf sejumlah $\mathrm{k}$ dari sebuah kata secara kontinuitas dibaca dari teks sumber hingga akhir dari dokumen.

4. Menghitung nilai hash dari setiap gram yang dihasilkan.

5. Memilih beberapa hasil hash menjadi dokumen fingerprinting.

\section{Algoritma Winnowing}

Algoritma winnowing merupakan algoritma yang digunakan dalam deteksi kesamaan menggunakan fungsi hashing. Winnowing adalah algoritma yang digunakan untuk melakukan proses document fingerprinting. Algoritma winnowing melakukan penghitungan nilai-nilai hash dari setiap k-gram, untuk mencari nilai hash selanjutnya digunakan fungsi rolling hash. Kemudian dibentuk window dari nilai-nilai hash tersebut. Dalam setiap window dipilih nilai hash minimum. Jika ada lebih dari satu hash dengan nilai minimum, dipilih nilai hash yang paling kanan. Kemudian semua nilai hash terpilih disimpan untuk dijadikan fingerprint dari suatu dokumen. Fingerprint ini yang akan dijadikan dasar pembanding kesamaan antara teks yang telah dimasukkan. Berikut merupakan persamaan untuk menghitung nilai hash

$H(C 1 \ldots C k)=c_{1} * b_{(k-1)}+c_{2} * b_{(k-2)}+\cdots+c_{(k-1)} * b_{k}+c_{k}$ (2.1)

Keterangan :

c : nilai ASCII karakter

$\mathrm{b}$ : basis (bilangan prima)

$\mathrm{k}$ : banyak karakter

Langkah perhitungan algoritma winnowing digambarkan pada Gambar 2.1 


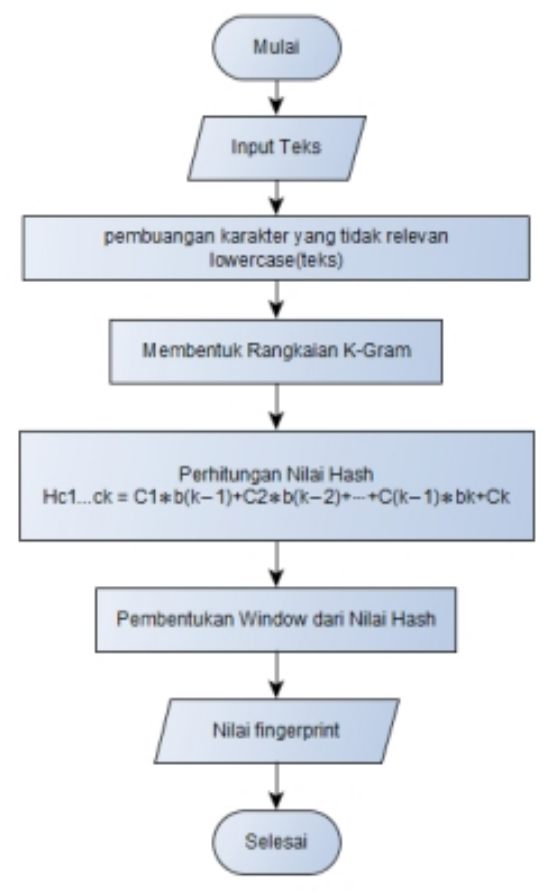

Gambar 2.1 Diagram alir algoritma metde certainty factor

\section{METODE PENELITIAN}

\section{Jenis Penelitian}

Jenis penelitan yang digunakan pada penelitian ini merupakan jenis penelitian pengembangan, karena tujuan penelitian adalah untuk membangun sebuah sistem rekomendasi. Penelitian pengembangan bertujuan untuk membuat dan mengembangkan suatu produk yang efektif untuk digunakan. Penelitian ini bukan jenis penelitian yang ditunjukkan untuk menemukan teori atau menguji kebenaran dari suatu teori dalam bentuk eksperimentasi.

\section{Tahapan Penelitian}

Tahapan penelitian ini meliputi tahap pengumpulan data dan tahap analisis data. Penelitian dimulai dengan mencari studi literatur, menentukan tempat penelitian dan wawancara yang kemudian dilanjutkan ke analisis data dan pembuatan sistem untuk merumuskan analisis kebutuhan dari sistem. Setelah analisis kebutuhan terpenuhi, proses selanjutnya yaitu perancangan dan implementasi meliputi desain, coding kemudian testing aplikasi yang dibangun. Jika terjadi error maka akan dilakukan perbaikan sistem. Tahap terakhir yaitu penyusunan laporan.

\section{Perancangan Sistem}

Perancangan sistem pada penelitian ini mengadopsi metode waterfall. Menurut Pressman (2001), Terdapat 5 tahapan pada modelwaterfall, yaitu analisis kebutuhan(requirements), desain, implementasi dan perawatan(maintenance).

\section{Analisis Kebutuhan Sistem}

Berdasarkan metode pengembangan sistem model waterfall, tahapan awal yang dilakukan adalah tahapan analisis. Tahapan analisis ini dilakukan terhadap objek penelitian untuk memperoleh kebutuhan-kebutuhan dari sistem yang dibangun, baik berupa kebutuhan fungsional maupun kebutuhan nonfungsional. Hasil analisa tersebut sangat mempengaruhi fungsionalitas sistem yang dibangun untuk dapat digunakan sesuai dengan fungsi dan kebutuhan pengguna.

\section{Desain Sistem}

Desain sistem merupakan tahapan untuk pemodelan dari sistem yang dibangun. Sistem mulai dirancang menggunakan Unified Modeling Languange (UML).

\section{Bussiness Process}

Gambaran umum sistem rekomendasi penentuan dosen menggunakan algoritma winnowing dapat digambarkan melalui sebuah business process. Seperti yang dapat kita lihat pada Gambar 4.1 yang menggambarkan data-data yang digunakan sebagai masukan, data keluaran, uses sistem yang dibangun, hingga goal dari sistem itu sendiri.

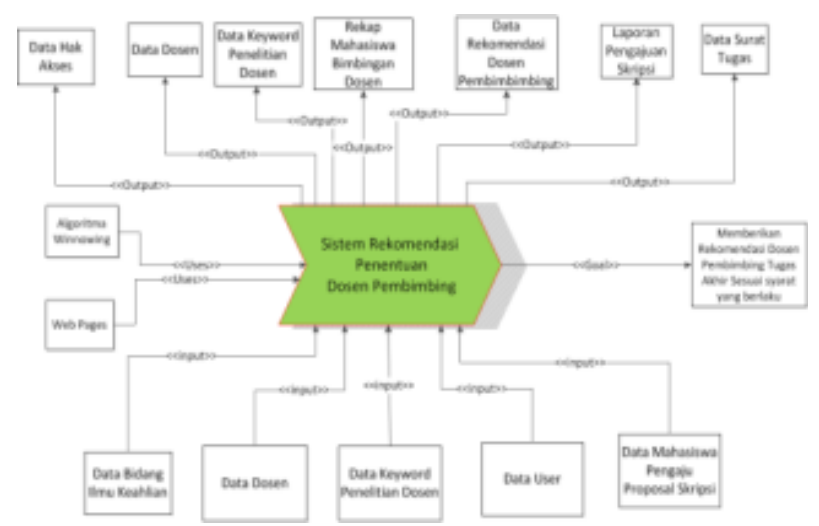

\section{Use Case Diagram}

Gambar 4.1. Bussiness Process

Use case diagram merupakan pemodelan yang dibuat untuk dapat menggambarkan interaksi antara aktor dengan sistem rekomendasi penentuan dosen menggunakan algoritma winnowing yang akan dibangun. Melalui use case diagram dapat diketahui interaksi yang dapat dilakukan setiap aktor terhadap sistem sesuai dengan hak akses yang dimiliki oleh masing-masing aktor atau pengguna. Pada Gambar 4.2 digambarkan use case diagram yang terdiri atas tiga aktor dengan dua puluh satu use case. 


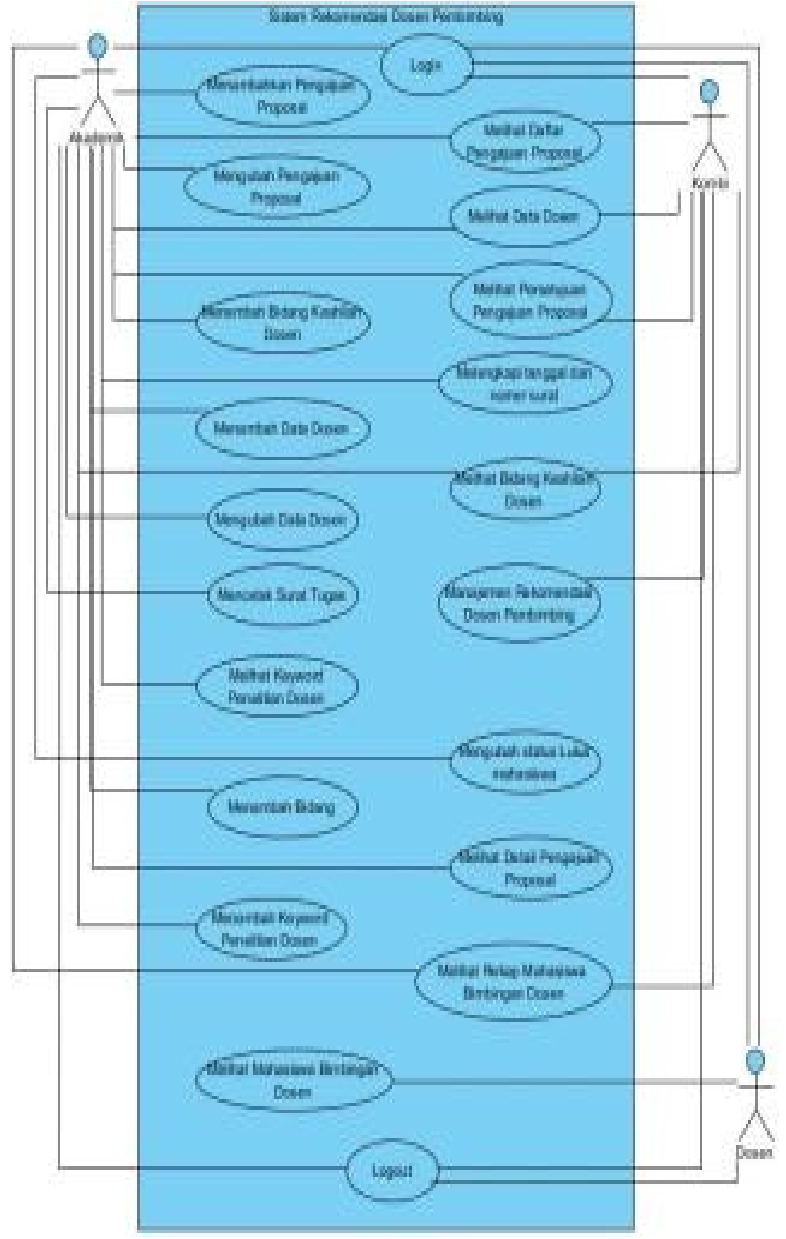

Gambar 4.2 Use Case Diagram

\section{Class Diagram}

Setelah melalui tahap pembuatan desain dengan sequence diagram, tahap selanjutnya yaitu membuat desain perancangan class diagram. Untuk class diagram sistem dapat dilihat pada Gambar 4.3

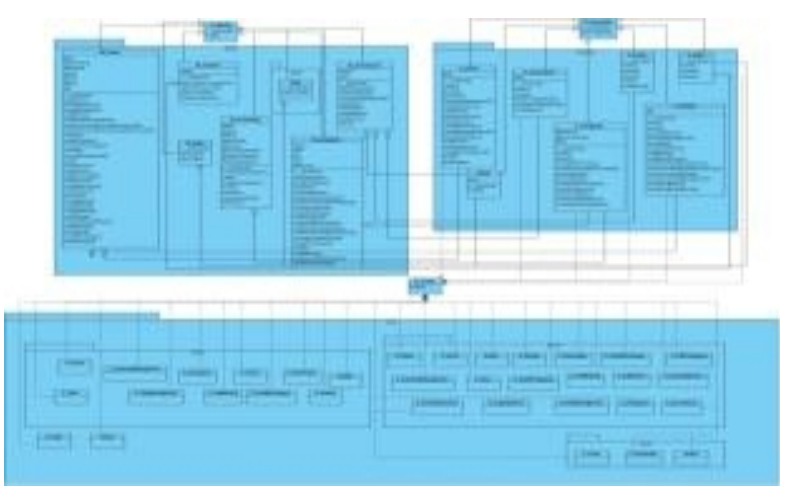

Gambar 4.3 Class Diagram

\section{Entity Relationship Diagram (ERD)}

Entity Relationship Diagram (ERD) sistem rekomendasi penentuan dosen pembimbing menggunakan algoritma winnowing merupakan gambaran komponen dan struktur database yang digunakan dalam pembuatan sistem. ERD yang diimplementasikan pada sistem ini terdiri dari 7 entitas sebagaimana terlihat pada Gambar 4.4 dibawah ini.

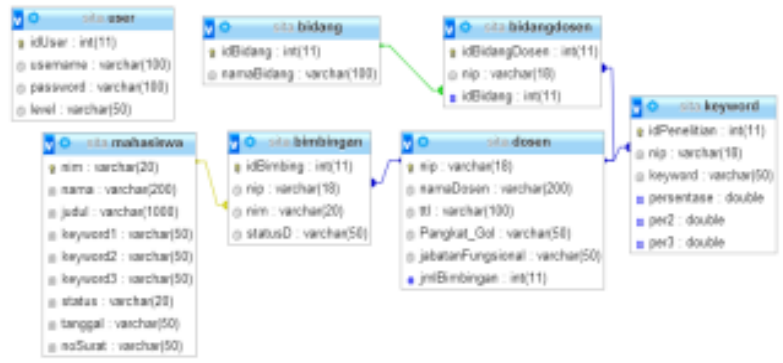

\section{Gambar 4.4 Entity Relationship Diagram (ERD)}

\section{HASIL PENELITIAN}

Pada bab ini menjelaskan mengenai hasil penelitian yang telah dilakukan serta pembahasan sistem rekomedasi penentuan dosen pembimbing skripsi menggunakan algoritma winnowing yang telah dibuat. Pembahasan dilakukan guna menjelaskan dan memaparkan bagaimana penelitian ini menjawab perumusan masalah serta tujuan dan manfaat dari penelitian ini seperti apa yang telah ditentukan pada awal penelitian.

Hasil Penerapan Perhitungan Metode Certainty Factor

Penerapan perhitungan algoritma winnowing pada sistem terletak pada fitur rekomendasi pengajuan proposal yang dapat diakses oleh user komisi bimbingan. Fitur terbesut memanfaatkan algotima winnowing untuk menemukan pola string yang sama menggunakan nilai fingerprint seperti yang telah dijelaskan pada tinjauan pustaka. Setiap kata yang terkandung dalam keyword proposal dan keyword jurnal penelitian akan dibandingkan . Sebagai contoh, perhitungan pada proses pencarian kemiripan akan dilakukan pada keyword penelitian dosen dan keyword yang diajukan mahasiswa yang dijadikan sample.

Berikut adalah contoh kasus penentuan dosen pembimbing pada Tabel 5.1 dan Tabel 5.2

Tabel 5.1 Data pengajuan proposal

\begin{tabular}{cccc}
\hline Nama & $\begin{array}{c}\text { Keyword 1 } \\
(\mathbf{k 1 )}\end{array}$ & $\begin{array}{c}\text { Keyword 2 } \\
(\mathbf{k 2})\end{array}$ & $\begin{array}{c}\text { Keyword 3 } \\
(\mathbf{k 3 )}\end{array}$ \\
\hline Jarwati & Algoritma & Sistem & Penentuan \\
& Winnowing & Rekomendasi & Dosen \\
& & & Pembimbing \\
\hline
\end{tabular}

Tabel 5.2 Data Penelitian Dosen

\begin{tabular}{cccc}
\hline Nama & $\begin{array}{c}\text { Keyword } \\
\text { 1(Kd1) }\end{array}$ & $\begin{array}{c}\text { Keyword 2 } \\
\text { (Kd2) }\end{array}$ & $\begin{array}{c}\text { Keyword 3 } \\
\text { (Kd2) }\end{array}$ \\
\hline Slamin & Graf & Sistem & Letak lampu \\
& & Informasi & kota \\
Slamin & Sistem & Naive Bayes & Kelayakan \\
& Pendukung & Classifier & Raskin \\
& Keputusan & & \\
Saiful & Deteksi & Plagiarisme & Algoritma \\
Bukhori & & & Winnowing \\
\hline
\end{tabular}

Untuk menghasilkan persentase, selanjutnya dilakukan perhitungan kesamaan antara keyword proposal $(\mathrm{k} 1, \mathrm{k} 2, \mathrm{k} 3)$ dengan keyword penelitian dosen (kd1, kd2, kd3). Langkah-langkah perhitungan persentase dari string matching adalah sebagai berikut: 
1. Langkah preprocessing, yaitu mengubah setiap keyword menjadi huruf kecil (lowercase) dan proses menghilangkan tanda baca.

a. Keyword topik mahasiswa :

\begin{tabular}{c|c|c}
$\begin{array}{c}\text { Algoritma } \\
\text { Winnowing }\end{array}$ & $\begin{array}{c}\text { Sistem } \\
\text { Rekomendasi }\end{array}$ & $\begin{array}{c}\text { Penentuan } \\
\text { Dosen } \\
\text { Pembimbing }\end{array}$ \\
\hline $\begin{array}{c}\text { algoritmawinn } \\
\text { owing }\end{array}$ & $\begin{array}{c}\text { sistemrekomend } \\
\text { asi }\end{array}$ & $\begin{array}{c}\text { penentuandosne } \\
\text { pembimbing }\end{array}$
\end{tabular}

b. Keyword penelitian dosen :

\begin{tabular}{|c|c|c|c|}
\hline \multirow{2}{*}{ Slamin } & Graf & $\begin{array}{l}\text { Sistem } \\
\text { Informasi }\end{array}$ & Letak lampu kota \\
\hline & graf & $\begin{array}{c}\text { Sistem } \\
\text { informasi }\end{array}$ & letaklampukota \\
\hline \multirow{2}{*}{ Slamin } & $\begin{array}{c}\text { Sistem Pendukung } \\
\text { Keputusan }\end{array}$ & $\begin{array}{c}\text { Naive Bayes } \\
\text { Classifier }\end{array}$ & $\begin{array}{l}\text { Kelayakan } \\
\text { Raskin }\end{array}$ \\
\hline & $\begin{array}{c}\text { sistempendukungk } \\
\text { eputusan } \\
\text { deteksi }\end{array}$ & $\begin{array}{c}\text { naivebayescla } \\
\text { ssifier } \\
\text { Plagiarisme }\end{array}$ & $\begin{array}{c}\text { kelayakanraskin } \\
\text { Algoritma } \\
\text { Winnowing }\end{array}$ \\
\hline $\begin{array}{c}\text { Saiful } \\
\text { Bukhori }\end{array}$ & deteksi & plagiarisme & $\begin{array}{c}\text { algoritmawinnow } \\
\text { ing }\end{array}$ \\
\hline
\end{tabular}

1. Membentuk gram pada teks dengan nilai gram tiga

2. Menghitung nilai hash pada setiap gram yang dihasilkan menggunakan proses rolling hash

3. Memetakan nilai hash kedalam window dengan nilai window tiga

4. Menentukan nilai fingerprint pada setiap window yang dihasilkan seperti pada Tabel 5.3

Tabel 5.3 Perhitungan Winnowing Mahasiswa

\begin{tabular}{|c|c|c|c|c|c|}
\hline Nama & \multicolumn{5}{|c|}{ Jarwati } \\
\hline Proses & Keyword 1 & Keyword 2 & & eyword & \\
\hline Preprocessing & $\begin{array}{c}\text { algoritmawinnowi } \\
\text { ng }\end{array}$ & sistemrekomendasi & Penentua & $\begin{array}{c}\text { ndosenp } \\
\text { ng }\end{array}$ & embimbi \\
\hline $\begin{array}{l}\text { Rangkaian } \\
\text { Gram }\end{array}$ & $\begin{array}{l}\text { alg lgo gor ori rit } \\
\text { itm tma maw awi } \\
\text { win inn nno now } \\
\text { owi win ing }\end{array}$ & $\begin{array}{l}\text { sis ist ste tem emr } \\
\text { mre rek eko kom } \\
\text { ome men end nda } \\
\text { das asi }\end{array}$ & $\begin{array}{l}\text { pen ene } \mathrm{n} \\
\text { and ndo } \\
\text { npe pem } \\
\text { mbi bin in }\end{array}$ & $\begin{array}{l}\text { en ent nt } \\
\text { dos ose } \\
\text { emb mbi } \\
\text { ig }\end{array}$ & $\begin{array}{l}\text { tu tua uan } \\
\text { sen enp } \\
\text { bim imb }\end{array}$ \\
\hline Nilai Hash & $\begin{array}{ll}13028 & 14312 \\
13798 & 14790 \\
15065 & 14090 \\
15332 & 14375 \\
13151 & 15664 \\
14025 & 14631 \\
14650 & 14845 \\
15664 & 14018\end{array}$ & $\begin{array}{cl}15185 & 14086 \\
15292 & 15256 \\
13534 & 14544 \\
15012 & 13509 \\
14277 & 14731 \\
14410 & 13531 \\
14507 & 13282 \\
13107 & \end{array}$ & $\begin{array}{l}14773 \\
13547 \\
15334 \\
13436 \\
13543 \\
13518 \\
14002\end{array}$ & $\begin{array}{l}13532 \\
14703 \\
13047 \\
14797 \\
14643 \\
14372 \\
14372 \\
14018\end{array}$ & $\begin{array}{l}14531 \\
15420 \\
14521 \\
15136 \\
14772 \\
13122 \\
13123\end{array}$ \\
\hline
\end{tabular}

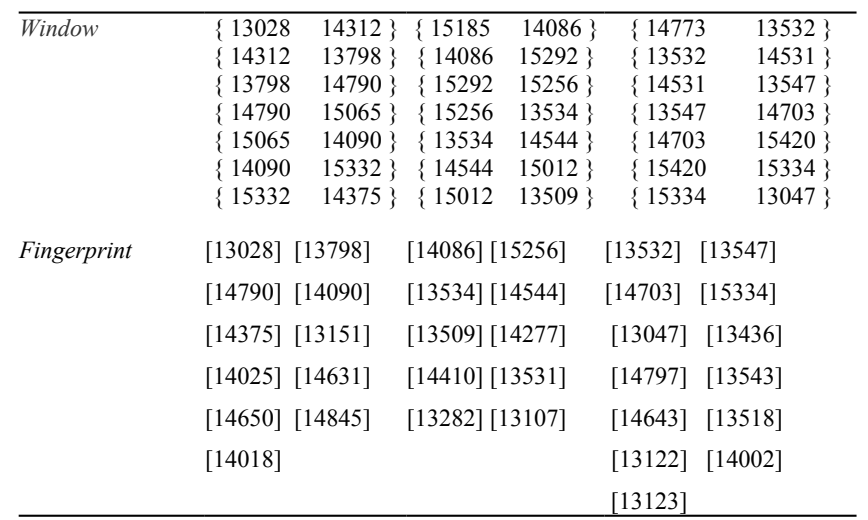

1. Langkah selanjutnya yaitu menghitung persentase kemiripan setiap fingerprint yang dihasilkan pada langkah 1 sampai 5.

2. Membandingkan fingerprint keyword mahasiswa 'Algoritma Winnowing' dengan keyword penelitian semua dosen seperti pada Tabel 5.4.

Tabel 5.4 Perhitungan winnowing dosen dan mahasiswa

\begin{tabular}{lll}
\hline \multicolumn{3}{c}{ Fingerprint } \\
\hline Mahasiswa(B) & Dosen(A) & Hitung Persentase \\
& & \\
\hline$[13028][13798][14790]$ & {$[13814]$} & Teks : Graf(A) dan \\
{$[14090][14375][13151]$} & & Algoritma Winnowing(B) \\
{$[14025][14631][14650]$} & $\mathrm{S}=\underline{\mathrm{A} \cap \mathrm{B}}$ \\
{$[14845][14018]$} & $\mathrm{A}=(0 / 12) * 100 \%=0 \%$
\end{tabular}

[13028][13798][14790] [14086] [15256] [13525] Teks : Sistem Informasi(A) [14090][14375][13151] [14017][13677] [14794] dan Algoritma

[14025][14631][14650] [14371] [13107] Winnowing(B)

[14845][14018]

$\mathrm{S}=\underline{\mathrm{A} \cap \mathrm{B}}$

$\mathrm{S}=(0 / 19) * 100=0 \%$

\begin{tabular}{|c|c|c|}
\hline$[13028][13798][14790]$ & {$[13594][13022] \quad[14232]$} & Teks : Letak Lampu \\
\hline$[14090][14375][13151]$ & {$[14538][14946]$} & Kota(A) dan Algoritma \\
\hline$[14025][14631][14650]$ & [14284] & Winnowing(B) \\
\hline$[14845][14018]$ & & $\begin{array}{l}\mathrm{S}=\underline{\mathrm{A} \cap \mathrm{B}} \\
\mathrm{AUB} \\
\mathrm{S}=(0 / 18) * 100=0 \%\end{array}$ \\
\hline
\end{tabular}

[13028][13798][14790] [14086][15256][13532] Teks : Sistem pendukung

[14090][14375][13151] [14522][13531][13494] Keputusan(A) dan

$[14025][14631][14650] \quad[14344][14550][13741] \quad$ Algoritma Winnowing(B)

$[14845][14018] \quad[13570][14955][15438] \quad \mathrm{S}=\underline{\mathrm{A} \cap \mathrm{B}}$

[15092] $\quad \begin{gathered}\text { A U B } \\ \mathrm{S}=(0 / 24) * 100=0 \%\end{gathered}$ 


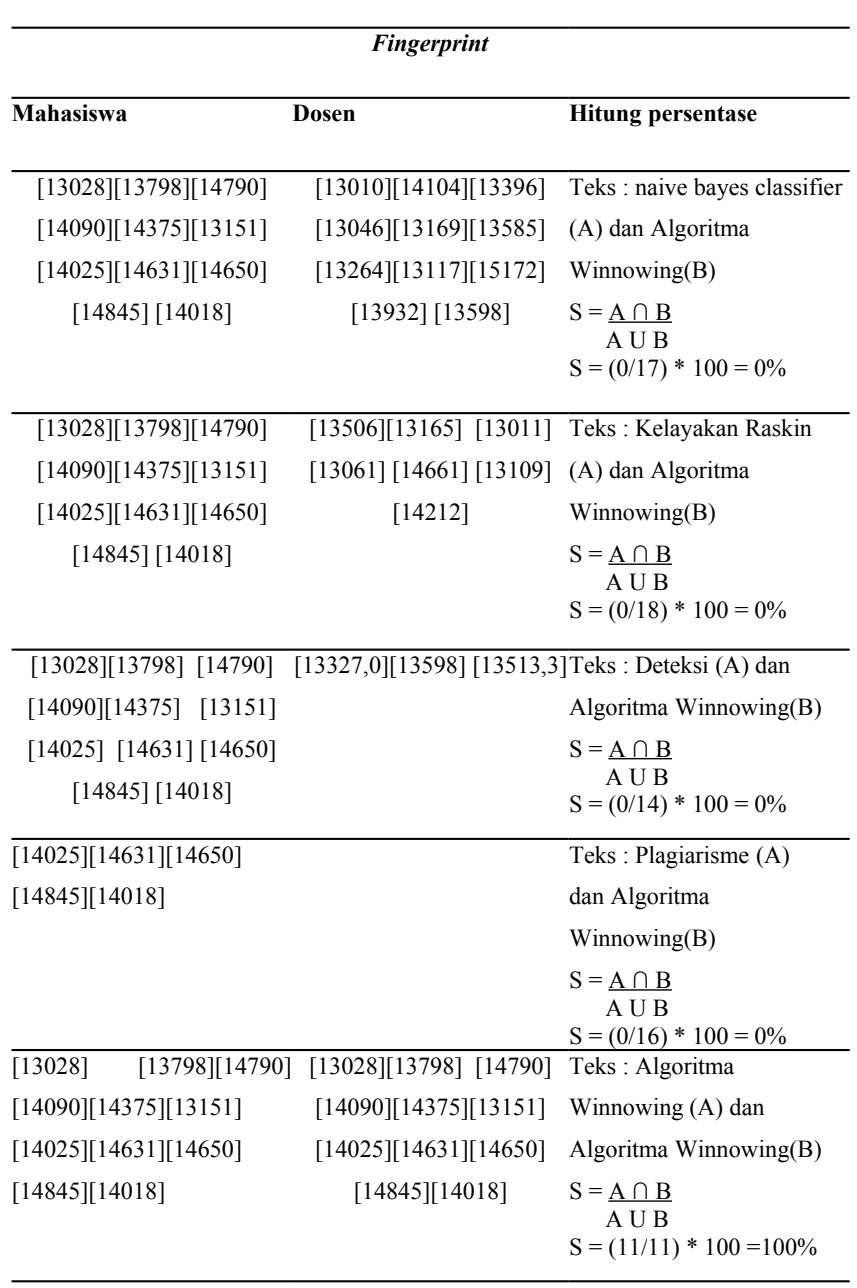

Membandingkan fingerprint keyword mahasiswa "sistem rekomendasi" dengan keyword penelitian semua dosen yaitu "graf", "sistem informasi", "letak lampu kota", "system pendukung keputusan", "naive bayes classifier", "kelayakan raskin", "deteksi", "plagiarisme", "algoritma winnowing" seperti pada Tabel 5.5.

Tabel 5.5 Perhitungan persentase kemiripan

\begin{tabular}{|c|c|c|}
\hline \multicolumn{3}{|c|}{ Fingerprint } \\
\hline Mahasiswa (B) & Dosen (A) & Hitung Persentase \\
\hline$[14086][15256]$ & & Teks : Graf(A) dan Sistem \\
\hline$[13534][14544]$ & [13814] & Rekomendasi (B) \\
\hline [13509] [14277] & & $\mathrm{S}=\underline{\mathrm{A} \cap \mathrm{B}}$ \\
\hline$[14410][13531]$ & & A U B \\
\hline$[13282][13107]$ & & \\
\hline$[14086][15256]$ & {$[14086][15256][13525]$} & Teks : Sistem \\
\hline$[13534][14544]$ & \multicolumn{2}{|c|}{ [14017] [13677] [14794] [14371]Informasi(A) dan Sistem } \\
\hline [13509] [14277] & [13107] & Rekomendasi (B) \\
\hline$[14410][13531]$ & & $\mathrm{S}=\underline{\mathrm{A} \cap \mathrm{B}}$ \\
\hline \multirow[t]{2}{*}[13282]{$[13107]$} & & A U B \\
\hline & & $\mathrm{S}=(0 / 18) * 100=0 \%$ \\
\hline$[14086][15256]$ & \multicolumn{2}{|c|}{$[13594][13022] \quad[14232][13048]$ Teks : Letak Lampu } \\
\hline$[13534][14544]$ & {$[14538][14946] \quad[14284]$} & Kota(A) dan Sistem \\
\hline$[13509][14277]$ & & Rekomendasi (B) \\
\hline$[14410][13531]$ & & $\mathrm{S}=\underline{\mathrm{A} \cap \mathrm{B}}$ \\
\hline [13282] [13107] & & $\begin{array}{c}\text { A U B } \\
\mathrm{S}=(0 / 17) * 100=0 \%\end{array}$ \\
\hline
\end{tabular}

\begin{tabular}{|c|c|c|}
\hline \multicolumn{3}{|c|}{ Fingerprint } \\
\hline Mahasiswa (B) & Dosen (A) & Hitung persentase \\
\hline$[14086][15256]$ & \multicolumn{2}{|c|}{ [13506] [13165] [13011] [13061]Teks : Kelayakan Raskin } \\
\hline [13534] [14544] & [14661] [13109] [14212] & (A) dan Sistem \\
\hline [13509] [14277] & & Rekomendasi (B) \\
\hline [14410] [13531] & & $S=\underline{A \cap B}$ \\
\hline [13282] [13107] & & $\begin{array}{c}\mathrm{AUB} \\
\mathrm{S}=(0 / 17) * 100=0 \%\end{array}$ \\
\hline$[14086][15256]$ & {$[14086][15256][13532]$} & Teks : Sistem pendukung \\
\hline [13534] [14544] & {$[14522]$} & Keputusan(A) dan Sistem \\
\hline [13509] [14277] & [13531] [13494] & Rekomendasi (B) \\
\hline$[14410][13531]$ & {$[14344][14550][13741]$} & $\mathrm{S}=\underline{\mathrm{A} \cap \mathrm{B}}$ \\
\hline [13282] [13107] & $\begin{array}{c}{[13570]} \\
{[14955][15438]}\end{array}$ & $\begin{array}{c}\text { A U B } \\
\mathrm{S}=(3 / 20) * 100=15 \%\end{array}$ \\
\hline$[14086][15256]$ & \multicolumn{2}{|c|}{ [13010][14104] [13396][13046] Teks : naive bayes } \\
\hline$[13534][14544]$ & \multirow{4}{*}{\multicolumn{2}{|c|}{$\begin{aligned} {[13169][13585][13264][13117] } & \text { classifier (A) dan Sistem } \\
{[15172][13932][13598] } & \text { Rekomendasi (B) } \\
& \mathrm{S}=\underline{\mathrm{A} \cap \mathrm{B}} \\
& \mathrm{S}=(0 / 21) * 100=0 \%\end{aligned}$}} \\
\hline [13509] [14277] & & \\
\hline$[14410][13531]$ & & \\
\hline$[13282][13107]$ & & \\
\hline$[14086][15256]$ & {$[13327][13598]$} & Teks : Deteksi (A) dan \\
\hline$[13534][14544]$ & {$[13513]$} & Sistem Rekomendasi (B) \\
\hline$[13509][14277]$ & & $\mathrm{S}=\underline{\mathrm{A} \cap \mathrm{B}}$ \\
\hline [14410] [13531] & & $\begin{array}{c}\text { A U B } \\
\mathrm{S}=(0 / 13) * 100=0 \%\end{array}$ \\
\hline$[13282][13107]$ & & \\
\hline$[14086][15256]$ & {$[14238][12975][13715]$} & Teks : Plagiarisme (A) \\
\hline$[13534][14544]$ & [13096] [14079] & dan Sistem Rekomendasi \\
\hline [13509] [14277] & & (B) \\
\hline$[14410][13531]$ & & $S=\underline{A \cap B}$ \\
\hline$[13282][13107]$ & & $\begin{array}{c}\text { A U B } \\
\mathrm{S}=(0 / 15) * 100=0 \%\end{array}$ \\
\hline$[14086][15256]$ & {$[13028][13798][14790][14090]$} & ] Teks : Algoritma \\
\hline [13534] [14544] & {$[14375][13151][14025][14631]$} & Winnowing (A) dan \\
\hline [13509] [14277] & {$[14650][14845][14018]$} & Sistem Rekomendasi (B) \\
\hline$[14410][13531]$ & & $\mathrm{S}=\underline{\mathrm{A} \cap \mathrm{B}}$ \\
\hline$[13282]$ [13107] & & $\begin{aligned} & \mathrm{A} U \mathrm{~B} \\
\mathrm{~S}= & (0 / 21) * 100=0 \%\end{aligned}$ \\
\hline
\end{tabular}

Langkah selanjutnya yaitu membandingkan fingerprint keyword mahasiswa "penentuan dosen pembimbing" dengan keyword penelitian semua dosen seperti langkah 7 dan langkah 8 yaitu "graf", "sistem informasi", "letak lampu kota", "system pendukung keputusan", "naive bayes classifier", "kelayakan raskin", "deteksi", "plagiarisme", "algoritma winnowing" seperti pada Tabel 5.6.

Tabel 5.6 Perhitungan persentase kemiripan

\begin{tabular}{|c|c|c|}
\hline \multicolumn{3}{|c|}{ Fingerprint } \\
\hline Mahasiswa (B) & Dosen (A) & Hitung Persentase \\
\hline$[13532][13547][14703] \quad[15334]$ & & Teks : Graf(A) dan \\
\hline$[13047][13436]$ & [13814] & Penentuan Dosen \\
\hline$[14797][13543][14643] \quad[13518]$ & & Pembimbing (B) \\
\hline \multirow[t]{3}{*}[13122]{$[14002] \quad[13123]$} & & $\mathrm{S}=\underline{\mathrm{A} \cap \mathrm{B}}$ \\
\hline & & A U B \\
\hline & & $\mathrm{S}=(0 / 14) * 100=0 \%$ \\
\hline$[13532][13547][14703] \quad[15334]$ & {$[14086][15256][13525]$} & Teks : Sistem \\
\hline [13047][13436] & {$[14017][13677][14794]$} & Informasi(A) dan \\
\hline$[14797][13543][14643] \quad[13518]$ & & Penentuan Dosen \\
\hline$[13122][14002] \quad[13123]$ & & Pembimbing (B) \\
\hline
\end{tabular}




\begin{tabular}{|c|c|c|}
\hline & {$[14371][13107]$} & $\begin{array}{l}\mathrm{S}=\underline{\mathrm{A} \cap \mathrm{B}} \\
\mathrm{A}=(0 / 21)^{*} * 100=0 \%\end{array}$ \\
\hline$[13532][13547][14703] \quad[15334]$ & {$[13594][13022][14232]$} & Teks : Letak Lampu \\
\hline$[13047][13436]$ & [13048] [14538][14946] & $\operatorname{Kota}(\mathrm{A})$ dan \\
\hline \multirow{3}{*}{$\begin{array}{c}{[14797][13543][14643] \quad[13518]} \\
{[13122][14002] \quad[13123]}\end{array}$} & {$[14284]$} & penentuan dosen \\
\hline & & pembimbing (B) \\
\hline & & $\begin{array}{l}\mathrm{S}=\underline{\mathrm{A} \cap \mathrm{B}} \\
\mathrm{AUB} \\
\mathrm{S}=(0 / 20) * 100= \\
0 \%\end{array}$ \\
\hline$[13532][13547][14703] \quad[15334]$ & {$[14086][15256][\mathbf{1 3 5 3 2}]$} & Teks : Sistem \\
\hline$[13047][13436]$ & {$[14522][13531][13494]$} & pendukung \\
\hline$[14797][13543][14643] \quad[13518]$ & {$[14344][14550][13741]$} & Keputusan(A) dan \\
\hline$[13122][14002]$ & {$[13570][14955][15438]$} & Penentuan Dosen \\
\hline \multirow[t]{2}{*}{ [13123] } & {$[15092]$} & Pembimbing (B) \\
\hline & & $\begin{array}{l}\mathrm{S}=\underline{\mathrm{A} \cap \mathrm{B}} \\
\mathrm{AUB} \\
\mathrm{S}=(1 / 25) * 100= \\
4 \%\end{array}$ \\
\hline$[13532][13547][14703] \quad[15334]$ & {$[13010][14104][13396]$} & Teks : naive bayes \\
\hline$[13047][13436]$ & [13046] [13169] [13585] & classifier (A) dan \\
\hline$[14797][13543][14643] \quad[13518]$ & [13264] [13117] [15172] & Penentuan Dosen \\
\hline \multirow[t]{2}{*}[13122]{$[14002] \quad[13123]$} & {$[13932][13598]$} & Pembimbing (B) \\
\hline & & $\begin{array}{l}S=\frac{A \cap B}{A U B} \\
S=(0 / 24) * 100=0 \%\end{array}$ \\
\hline$[13532][13547][14703]$ [15334] & [13506] [13165] [13011] & Teks : Kelayakan \\
\hline$[13047][13436]$ & [13061] [14661] [13109] & Raskin (A) dan \\
\hline$[14797][13543][14643] \quad[13518]$ & {$[14212]$} & Penentuan Dosen \\
\hline \multirow[t]{2}{*}[13122]{$[14002] \quad[13123]$} & & Pembimbing (B) \\
\hline & & $\begin{array}{l}\mathrm{S}=\frac{\mathrm{A} \cap \mathrm{B}}{\mathrm{AUB}} \\
\mathrm{S}=(0 / 20) * 100= \\
0 \%\end{array}$ \\
\hline$[13532][13547][14703] \quad[15334]$ & {$[13327][13598]$} & Teks : Deteksi (A) \\
\hline$[13047][13436]$ & [13513] & dan Penentuan Dosen \\
\hline$[14797][13543][14643] \quad[13518]$ & & Pembimbing (B) \\
\hline$[13122][14002] \quad[13123]$ & & $\begin{array}{l}S=\frac{A \cap B}{A U B} \\
S=(0 / 16) * 100=0 \%\end{array}$ \\
\hline$[13532][13547][14703][15334]$ & {$[14238][12975][13715]$} & Teks : Plagiarisme \\
\hline$[13047][13436]$ & [13096] [14079] & (A) dan Penentuan \\
\hline$[14797][13543][14643] \quad[13518]$ & & Dosen Pembimbing \\
\hline \multirow[t]{2}{*}[13122]{$[14002] \quad[13123]$} & & (B) \\
\hline & & $\begin{array}{l}\mathrm{S}=\frac{\mathrm{A} \cap \mathrm{B}}{\mathrm{AUB}} \\
\mathrm{S}=(0 / 18) * 100= \\
0 \%\end{array}$ \\
\hline$[13532][13547][14703] \quad[15334]$ & {$[13028][13798][14790]$} & Teks : Algoritma \\
\hline$[13047][13436]$ & {$[14090][14375][13151]$} & Winnowing (A) dan \\
\hline$[14797][13543][14643] \quad[13518]$ & {$[14025][14631][14650]$} & Sistem Rekomendasi \\
\hline \multirow[t]{2}{*}[13122]{$[14002] \quad[13123]$} & {$[14845][14018]$} & (B) \\
\hline & & $\begin{array}{l}\mathrm{S}=\underline{\mathrm{A} \cap \mathrm{B}} \\
\mathrm{AUB} \\
\mathrm{S}=(0 / 24) * 100=0 \%\end{array}$ \\
\hline
\end{tabular}

Langkah selanjutnya yaitu menghitung nilai rata-rata dari persentase yang telah dihitung. Berikut merupakan cara menghitung rata-rata persentase setiap dosen : a. Alternatif 1 (Slamin) memiliki 6 keyword dengan 18 kali perulangan yang masing-masing di cocokan dan dihasilkan nilai berikut :

Graf - Algoritma Winnowing $=0 \%$

Sistem Informasi - Algoritma Winnowing $=0 \%$

Letak Lampu Kota - Algoritma Winnowing $=0 \%$

Sistem Pendukung Keputusan - Algoritma Winnowing = $0 \%$

Naive Bayes Classifier - Algoritma Winnowing $=0 \%$

Kelayakan Raskin - Algoritma Winnowing $=0 \%$

Graf - Sistem Rekomendasi $=0 \%$

Sistem Informasi - Sistem Rekomendasi $=0 \%$

Letak Lampu Kota - Sistem Rekomendasi $=0 \%$

Sistem Pendukung Keputusan - Sistem Rekomendasi $=$ $15 \%$

Naive Bayes Classifier - Sistem Rekomendasi $=0 \%$

Kelayakan Raskin - Sistem Rekomendasi $=0 \%$

Graf - Penentuan Dosen Pembimbing $=0 \%$

Sistem Informasi-Penentuan Dosen Pembimbing $=0 \%$

Letak Lampu Kota - Penentuan Dosen Pembimbing $=0 \%$

Sistem Pendukung Keputusan Penentuan Dosen

Pembimbing $=4 \%$

Naive Bayes Classifier - Sistem Rekomendasi $=0 \%$

Kelayakan Raskin - Sistem Rekomendasi $=0 \%$

Nilai Rata-Rata $=(19 / 16) \%=1,18 \%$

b. Alternatif 2 (Saiful Bukhori) memiliki 6 keyword dengan 18 kali perulangan yang masing-masing di cocokan dan dihasilkan nilai berikut:

Deteksi- Algoritma Winnowing $=0 \%$

Plagiarisme - Algoritma Winnowing $=0 \%$

Algoritma Winnowing - Algoritma Winnowing $=100 \%$

Deteksi- Sistem Rekomendasi $=0 \%$

Plagiarisme - Sistem Rekomendasi $=0 \%$

Algoritma Winnowing - Sistem Rekomendasi $=0 \%$

Deteksi- Penentuan Dosen Pembimbing $=0 \%$

Plagiarisme - Penentuan Dosen Pembimbing $=0 \%$

Algoritma Winnowing - Penentuan Dosen Pembimbing $=$ $0 \%$

Nilai Rata-Rata $=(100 / 6) \%=16,67 \%$

Langkah terakhir adalah mengurutkan nilai rata-rata persentase alternatif terbesar hingga terkecil. Sehingga dihasilkan rekomendasi sebagai berikut :

a. Saiful Bukhori dengan persentase 16,67\%

b. Slamin dengan persentase $1,18 \%$

Dari hasil persentase diatas, maka dosen pembimbing yang direkomendasikan oleh sistem sesuai dengan kompetensi dosen adalah Saiful Bukhori.

Hasil Pembuatan Sistem Rekomendasi Penentuan Dosen Pembimbing Menggunakan Algoritma Winnowing

Hasil pembuatan sistem dalam penelitian ini adalah sistem rekomendasi penentuan dosen pembimbing menggunakan algoritma winnowing. Terdapat batasan yang bisa dilakukan sistem yakni sistem mampu memberikan rekomendasi sesuai dengan kata kunci penelitian topik mahasiswa tanpa memperhatikan nama dosen pembimbing yang diajukan mahasiswa . Sistem hanya mencari kesamaan pola kata kunci tanpa memperhatikan kesamaan kata dalam Kamus Bahasa Indonesia. User yang dapat mengakses 
sistem dibagi kedalam tiga hak akses yaitu akademik, komisi bimbingan dan dosen. Akademik merupakan user sistem yang mendapat hak penuh terhadap proses input data. Komisi bimbingan memiliki hak terhadap penentuan dosen pembimbing. Sedangkan dosen hanya memiliki hak untuk melihat jumlah bimbingan skripsi. Berikut ini merupakan tampilan fitur-fitur yang terdapat dalam sistem.

\section{Fitur Login}

Fitur ini merupakan fitur autentifikasi untuk dapat mengakses terhadap fitur-fitur yang berada di dalam sistem. Halaman ini digunakan oleh user akademik, user komisi bimbingan maupun user dosen sebelum bisa mengakses halaman beranda sistem. User diwajibkan memiliki username dan password untuk bisa mengakses fitur-fitur yang ada di dalam sistem. Pengecekan hak akses user juga dilakukan pada saat proses login dikerjakan. User dengan level akademik diarahkan ke halaman utama akademik, user level komisi bimbingan akan diarahkan ke halaman utama komisi bimbingan dan user dengan level dosen diarahkan ke halaman utama dosen

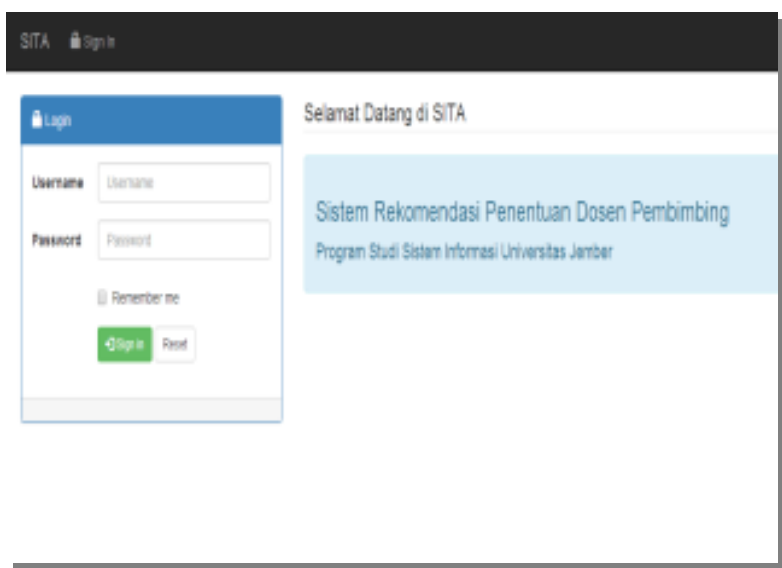

Gambar 5.2 Tampilan halaman login

\section{Fitur Tambah Pengajuan}

Fitur tambah pengajuan merupakan fitur yang dilakukan oleh akademik untuk manajemen pengajuan proposal. Tampilan halaman tambah data pengajuan pada Gambar 5.3.

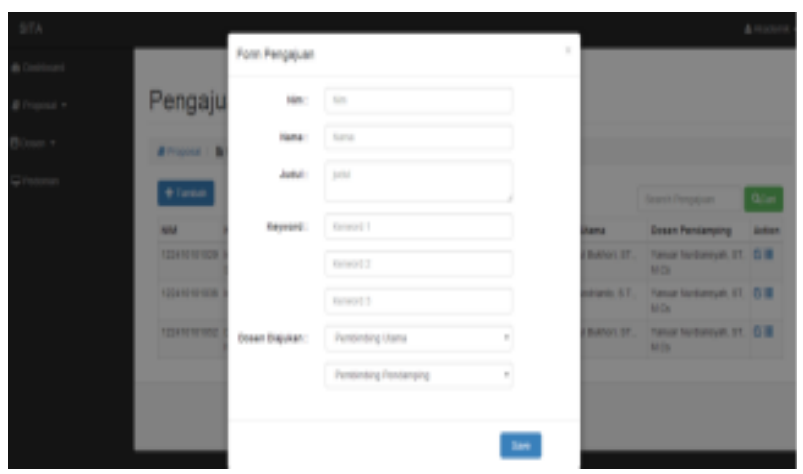

Gambar 5.3 Fitur data gejala

\section{Fitur Data Persetujuan}

Fitur melihat data pengajuan merupakan fitur yang dilakukan oleh akademik untuk mengelola data surat tugas seperti melengkapi surat tugas, mencetak surat tugas, dan mengubah status mahasiswa. Tampilan halaman data persetujuan dapat dilihat pada Gambar 5.3.

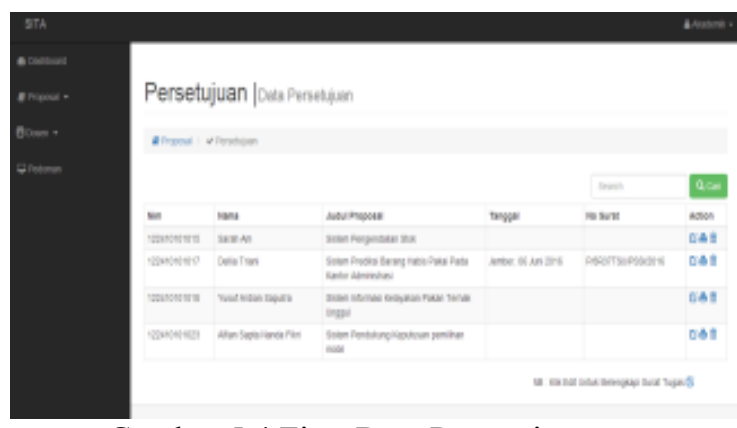

Gambar 5.4 Fitur Data Persetujuan

\section{Fitur Data Rekap bimbingan}

Fitur data rekap bimbingan merupakan fitur yang dilakukan oleh akademik dan komisi bimbingan untuk melihat rekap data bimbingan dosen. Data rekap bimbingan teridiri dari data dosen, data jumlah bimbingan, dan tombol detail untuk melihat banyak detail bimbingan. Ketika pengguna memilih tombol detail, maka sistem akan menampilkan halaman detail bimbingan dosen. Tampilan halaman data rekap bimbingan dan detail bimbingan dapat dilihat pada Gambar 5.5 dan Gambar 5.6.

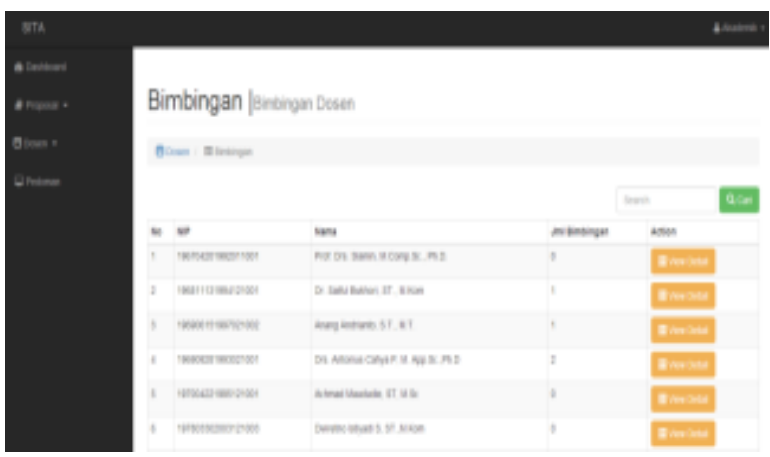

Gambar 5.5 Halaman rekap data bimbingan

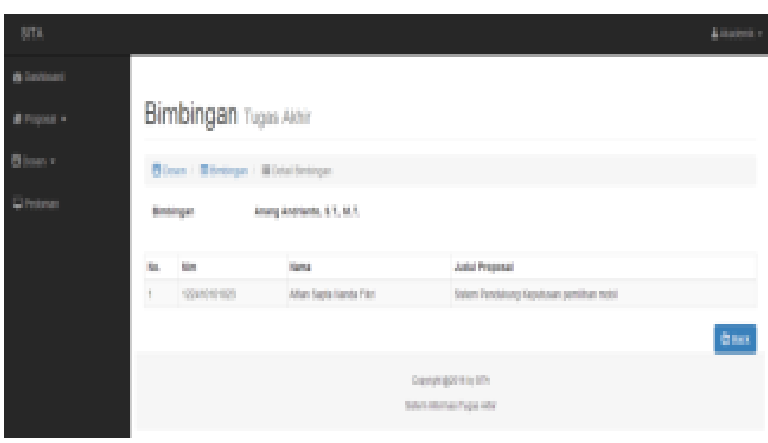

Gambar 5.6 Halaman detail bimbingan

\section{Fitur Manajemen Rekomendasi dosen}

Manajemen rekomendasi dosen merupakan fitur yang dilakukan oleh komisi bimbangan. Fitur ini dapat menampilkan hasil rekomendasi dosen pembimbing utama dan dosen pembimbing pendamping. Halaman rekomendasi dosen dapat dilihat pada Gambar 5.7. 


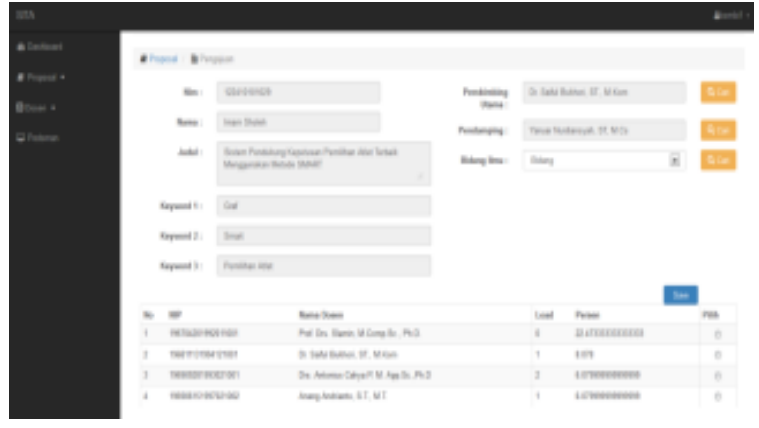

Gambar 5.7 Halaman rekomendasi dosen pembimbing

\section{Pembahasan Pada Sistem Rekomendasi Dosen Pembimbing}

Pembahasan ini mencakup hasil dari diskusi yang telah dilakukan oleh peneliti dengan dosen, akademik dan komisi bimbingan. Proses pembahasan yang dilakukan mendapatkan hasil bahwa sistem yang telah dibuat dapat membantu memberikan rekomendasi dosen pembimbing skripsi sesuai dengan aturan yang berlaku pada prodi Sistem Informasi Universitas Jember.

Berdasarkan hasil diskusi atau tanya jawab dengan komisi bimbingan dan dosen dapat disimpulkan bahwa aplikasi ini dapat membantu komisi bimbingan dalam memilih dosen pembimbing berdasar pada kata kunci penelitian dosen dan sesuai dengan kompetensi setiap dosen, namun masih dibutuhkan penambahan kriteria bobot dari alasan pemilihan dosen pembimbing. Ada beberapa alasan mahasiswa memilih dosen untuk menjadi pembimbing, diantaranya karena hanya senang dengan dosen, karena topik penelitian lebih dikuasai dosen, atau karena memiliki projek penelitian dengan dosen tersebut. Hasil diskusi juga membahas mengenai kelebihan dan juga keterbatasan sistem rekomendasi penentuan dosen pembimbing. Kelebihan dan keterbatasan sistem, yaitu :

\section{Kelebihan Sistem}

Dari hasil pembuatan sistem, penulis dapat menganalisis kelebihan dari sistem yang dibuat yaitu :

a. Pengguna harus melakukan login jika ingin menggunakan sistem. Hal ini dimaksudkan untuk keamanan data yang dimiliki oleh pengguna.

b. Data perhitungan yang dihasilkan oleh sistem akurat karena perhitungan dilakukan oleh sistem sehingga hasil perhitungan algoritma winnowing yang dihasilkan bernilai benar.

c. Sistem mampu menampilkan pesan ketika terjadi error. Hal ini memudahkan pengguna untuk mengetahui bahwa terjadi kesalahan pada saat menjalankan sistem.

d. Sistem ini bersifat dinamis karena dalam pengimplementasiannya, data keyword yang digunakan dalam penelitian ini dapat ditmbah sesuai dengan perkembangan penelitian dosen.

e. Hasil rekomendasi berdasar pada aturan yang berlaku pada Program Studi Sistem Informasi Universitas Jember, sehingga sistem ini dapat memberikan rekomendasi yang tepat.

f. Sistem rekomendasi yang dihasilkan potensial untuk diterapkan diseluruh unit kerja Universitas Jember

\section{Keterbatasan Sistem}

Dari hasil pembuatan sistem, penulis dapat menganalisis kelemahan dari sistem yang dibuat yaitu :

1. Sistem yang dibuat memiliki kekurangan yakni sistem hanya mampu memberikan rekomendasi berdasar pada keyword penelitian dosen tanpa memperhatikan alasan pengajuan dosen pembimbing oleh mahasiswa.

2. Sistem rekomendasi dosen pembimbing hanya memberikan rekomendasi berdasarkan kata kunci yang dibandingkan tanpa memperhatikan sinonim kata dan kata dalam bahasa asing.

\section{KESIMPULAN DAN SARAN}

Kesimpulan dari penelitian yang telah dilakukan adalah: a. Penerapan algoritma winnowing digunakan pada sistem rekomendasi penentuan dosen pembimbing untuk memberikan perhitungan kesamaan antara topik penelitian mahasiswa dengan penelitian yang pernah dilakukan dosen dengan mebandingkan kata kunci pada setiap penelitian dan topik. Langkah awal yakni menentukan nilai gram dan window untuk dapat melakukan perhitungan kesamaan. Selanjutnya memasukkan data proposal pengajuan untuk dilakukan proses rekomendasi dan approval. Dari data tersebut, selanjutnya dihitung nilai kemiripan antara kata kunci topik yang ada pada data pengajuan dan data kata kunci penelitian dosen. Hasil dari perhitungan yang didapatkan adalah persentase kesamaan kata kunci pada setiap dosen yang diurutkan dari nilai terbesar. Hal yang mempengaruhi hasil persentase adalah jumlah kata kunci penelitian dosen. Semakin banyak jumlah penelitian dosen, maka rekomendasi yang dihasilkan bersifat umum, sedangkan apabila semakin sedikit kata kunci penelitian maka rekomendasi akan bersifat khusus. Sehingga apabila ada satu kecocokan pada proses string matching yang dimiliki oleh dosen dengan jumlah penelitian yang sedikit, maka rekomendasi akan lebih akurat.

b. Sistem rekomendasi penetuan dosen pembimbing menggunakan algoritma winnowing telah berhasil dibangun berbasis website dengan 3 hak akses yaitu akademik, komisi bimbingan dengan fitur utama adalah fitur pengajuan proposal yang dilakukan oleh akademik dan fitur rekomendasi dosen pembimbing yang dilakukan oleh komisi bimbingan. Sistem dikembangkan dengan mengadopsi model waterfall. Model waterfall digunakan karena kebutuhan sistem telah bisa didefinisikan di awal. Tahap pengembangan dilakukan dengan tahap analisis kebutuhan, desain, penulisan kode program, pengujian dan pemeliharaan. Analisis kebutuhan dilakukan dengan cara mencari kebutuhan fungsional dan non fungsional yang dibutuhkan untuk membangun sistem. Tahap desain sistem dilakukan dengan melakukan perancangan sistem dengan membuat beberapa diagram yang akan digunakan sebagai acuan dalam penulisan kode program. Selanjutnya dilakukan penulisan kode program dengan menggunakan bahasa pemrograman $P H P$, framework CodeIgniter, dan database manajemen $M y S Q L$. Tahap pengujian dilakukan setelah penulisan kode program yakni dengan melakukan pengujian black box dan white box. Tahap terakhir yakni melakukan pemeliharaan untuk mengetahui fungsionalitas sistem secara berkala. 
Saran

Adapun saran yang ditujukan untuk memberikan masukan yang lebih baik yaitu :

a. Sistem rekomendasi dosen pembimbing yang akan dikembangkan selanjutnya perlu ditambah bobot alasan pemilihan dosen oleh mahasiswa, sehingga rekomendasi yang di dapat akan lebih akurat.

b. Sistem rekomendasi dosen pembimbing yang akan dikembangkan selanjutnya akan lebih baik jika dapat mendeteksi sinonim kata sehingga persentase yang dihasilkan lebih tinggi dan memiliki tingkat akurasi rekomendasi yang besar.

\section{DAFTAR PUSTAKA}

[1] Khoiri, S. W. (2015). Pedoman Penulisan Skripsi FKM UNEJ. Jember: FKM UNEJ.

[2] Kurniawati, W. (2008). Perbandingan pendekatan Deteksi Plagiarism Dokumen Dalam Bahasa Inggris. Seminar Ilmiah Nasional Komputer dan Sistem Intelijen , 255-260.

[3] Pertiwi. (2015). Implementasi Algoritma Pencocokan String pada Aplikasi Pengarsipan Berbasis Web. EXTERNAL JOURNAL , 1-8.

[4] Presman, R. (2001). Software Engineering a practitioner's approach (5 ed.). New York: McGrawHill. 